\title{
Dispersal strategies of benthic species and water current variability in the Corsica Channel (Western Mediterranean)*
}

\author{
STEFANO ALIANI and ROBERTO MELONI \\ Institute for Physical Oceanography CNR. Forte S.Teresa, Pozzuolo di Lerici, 19036 La Spezia, Italy. \\ E-mail: aliani@estosf.santateresa.enea.it
}

\begin{abstract}
SUMMARY: Macrofauna and their dispersal strategies were identified in the fouling communities settling on current meter moorings deployed in the Corsica Channel. Oceanographic arrays provided time series of water current and substratum for colonisation of fauna. Larvae, sexual propagules, juveniles have different lengths of the planktonic phase. Some of these strategies are time-limited but others could survive indefinitely in the plankton. Current measurements indicate that fluxes are directed northward with reduced variability in direction and some fluctuations in magnitude with greater speeds in winter. The Corsica Channel is a one way gate for water fluxes from the Tyrrhenian Sea toward the Ligurian Sea. This gate could be "open" or "closed" for biological transport if length of planktonic phases and magnitude of current are consistent with the distances that dispersal forms have to travel to reach a suitable habitat. Strategies with an "unlimited" planktonic phase are less influenced by current variability.
\end{abstract}

Key words: dispersal strategies, physical-biological coupling, Corsica Channel, Western Mediterranean, current variability

\section{INTRODUCTION}

Traditional studies stress that variable rates of recruitment are the primary regulators of abundance and distribution of many marine organisms (Thorson, 1950). Ecologists, especially those studying benthic communities, have concentrated primarily on interactions between adults inside communities, but dissatisfaction has arisen with explanations only in terms of competition, predation and physical factors (Giangrande et al. 1994). In the last decade more attention had been focused on recruitment and there has been a return of the idea (supply side ecology) that dynamics

\footnotetext{
*Received 7 July, 1998. Accepted 5 March, 1999
}

in adult populations are strongly related to arrival rates of larvae (Roughgarden et al. 1987). The importance of the control exerted by physical transport processes on population and community dynamics matching the effect of local processes as predation or competition has been stressed (Lewin, 1986).

Many aspects of short and long range dispersal have received attention from scientists and some authors propose that length of larval cycle directly influences the distribution of organisms: the longer the period the wider the distribution of organisms (Thorson, 1950; Mileikovsky, 1968; 1971; Scheltema, 1971). According to these authors, several different types of larval development can be found in marine bottom invertebrates: 
- Direct, if development is in the eggs released in the environment: they are protected by egg capsules until they metamorphose: larval pelagic phase is absent;

- Viviparous, if complete development occurs in the body of parents; and

- Pelagic, if larvae develop in the plankton: this phase, dominant in benthic species, presents two sub-types:

a) Lecithotrophic development: larvae feed during the pelagic stage on their own food reserves; and

b) Planktotrophic development: larvae feed actively during pelagic life. This type of development can be short or very long; if larvae remain in the plankton for six weeks or less they are called actaeplanic, if they develop over a period exceeding two months, delaying settlement for 6-12 months they are called teleplanic (Scheltema, 1988).

According to Scheltema (1971) the probability of successful larval dispersal depends upon the drift coefficient, the advective component of transport, and the survival coefficient, the length of the planktonic (larval) phase.

This hypothesis has caused considerable discussion (Bhaud, 1998). Transoceanic transport of molluscs appears to agree to the general assumption that there is a direct relationship between length of larval period and geographical distribution of species (Scheltema, 1988) but some exceptions were found (Johannesson, 1988) and many factors were discovered influencing the distribution of species (Bhaud, 1983; 1993). Species with a short larval stage and apparently short dispersal distances are, nonetheless, widely distributed and populations can exhibit greater geographical range than expected from larval characteristics (Johannesson, 1988; Jamada, 1989).

The role of the larval phase for long distance transport was thus criticised and become to be considered less important. Species can also spread by other stages than larvae. For example, adults can survive in the water column where they are advected by water currents and where they play a crucial role in water column ecology (Madin et al. 1996). Rafting objects are a suitable substratum for transport (De Vantier, 1992) and byssus drifting is a common tool for many molluscs (Lane et al. 1985).

Studies of the dispersal of benthic invertebrates in the Mediterranean are rare (Thiriot-Quievreux, 1969; Bouchet and Taviani, 1992; Harmelin and d'Hondt, 1992; Aliani and Meloni, 1996; Pedrotti and Fenaux, 1996) and a simple checklist of the species transported by main Mediterranean currents is almost unknown (Astraldi et al. 1995; Aliani et al. 1998).

This work is part of a long time project aimed at monitoring species migration in the western Mediterranean. Here we focus on the species transported by water masses from the Tyrrhenian Basin to the Ligurian Basin through the Corsica Channel (Western Mediterranean) that settle on current meter moorings. Current meter moorings have been regularly deployed at sea to collect physical data but fouling on these moorings was always considered a problem and previously the information provided by fouling species was lost by cleaning the meters.

We now propose to use these fouling communities to monitor species migration and identify the combined contribution of their dispersal strategies and water current variability in maintaining the isolation between the two basins.

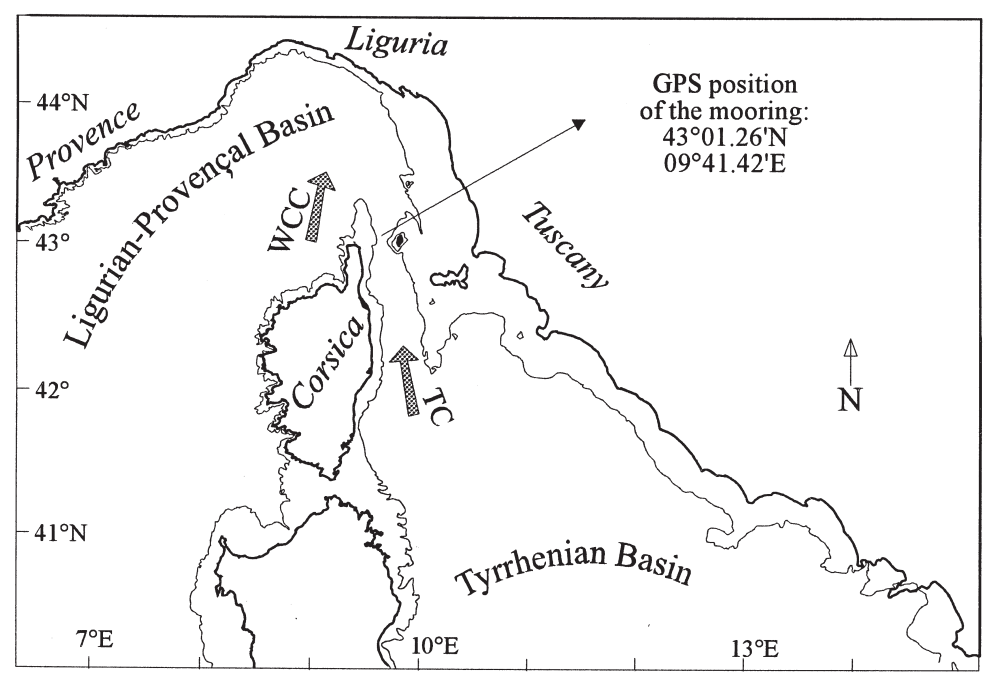

FIG. 1. - The Tyrrhenian Sea and the Ligurian-Provençal Basin. 


\section{The Corsica Channel}

The main connection from the Tyrrhenian Basin to the Ligurian-Provençal Basin is through a narrow passage about $100 \mathrm{~km}$ long ending in a bottle-neck passage between Corsica and Capraia Islands and separating the Island of Capraia and the Tuscan continental shelf from the Island of Corsica (Fig. 1). The Corsica Channel has, at its narrowest section, a surface width of $30 \mathrm{~km}$ and a maximum depth of about 460 meters. It is the only passage, which interest water masses of different origin being the limit between Modified Atlantic Water (MAW) and Intermediate Levantine Water (LIW) below the Tuscan continental shelf.

Southern waters that fill the northern Liguran Basin occur in two main currents running along each side of Northern Corsica: the West Corsica Current (WCC) and the Tyrrhenian Current (TC) passing through the Corsica channel between Capraia and Corsica (Artale et al., 1994). The Tyrrhenian current mainly flows northward with strong intensities (Hopkins, 1988; Artale and Gasparini, 1990).

The Corsica Channel is also a biological boundary since it separates two different biogeographical regions. Flora and fauna in the northern region are characterised by a marked reduction in subtropical elements and by the presence of species adapted to cool conditions that do not exist in the southern basin (Bianchi and Morri, 1994).

The Tyrrhenian current permits southern warm species to reach the Ligurian basin passing through the Corsica Channel (Astraldi et al. 1995) which can be considered a forced passage also for fauna exchanges. Although benthic fauna has been previously studied in this area (Albertelli et al., 1981; Emig, 1985; Balduzzi et al., 1986; Abbiati et al., 1991; Bianchi et al., 1993, Aliani, 1994; Aliani et al., 1995), the dispersal of species has not been studied in detail.

\section{MATERIAL AND METHODS}

An oceanographic mooring was positioned in the middle of the Corsica Channel. It was composed of four yellow Resinex syntactic foam buoys $(\Phi=60$ $\mathrm{cm}$ ), four RCM 7 Aanderaa current meters and two acoustic releasers (Fig. 2). Maximum depth was 430 meters and the top of the mooring was $50 \mathrm{~m}$ deep. Instruments were deployed on 11 June 1993 and removed on 28 December 1993. Current speed and direction were measured every 30 minutes.

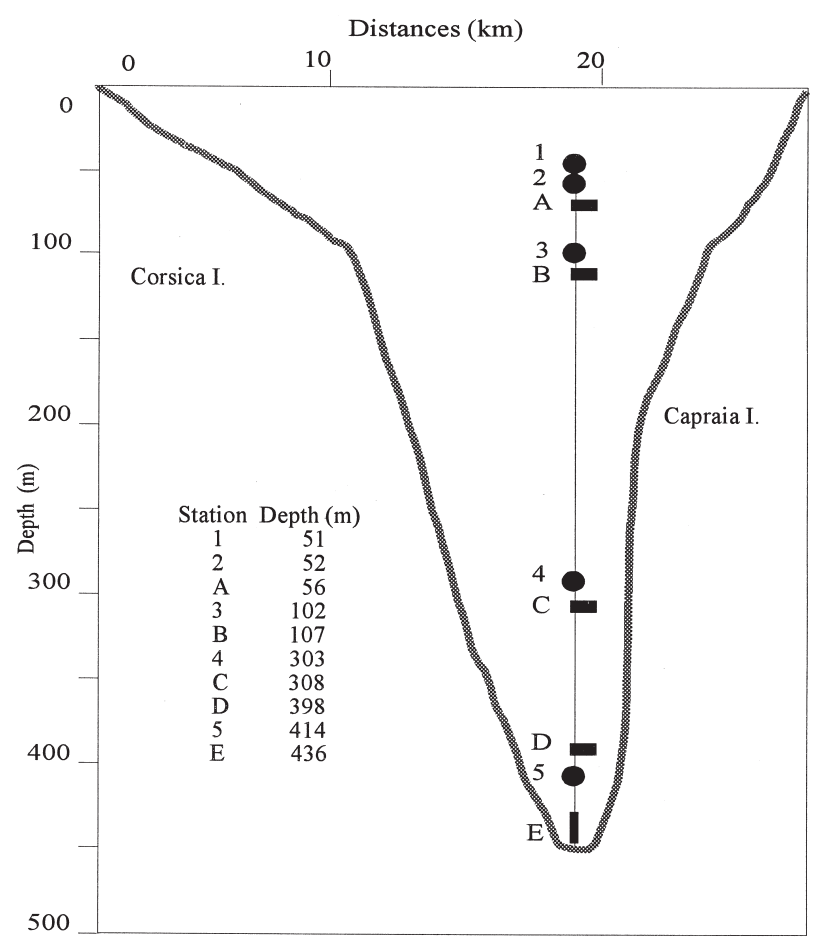

FIG. 2. - Cross section of the Corsica Channel between Cape Corse and Capraia Island.

Sampling stations for fauna were buoys (indicated with numbers), current meters and releasers (indicated with letters); all these items constituted the substratum for settlement. Macrobenthic specimens were collected by scraping all the organisms from buoys and current meters. Samples were fixed in $10 \%$ formaldehyde in seawater.

\section{RESULTS AND DISCUSSION}

\section{Water current}

Time series of current speed and direction show little variability in current direction as suggested by Astraldi and Gasparini (1992); there were stronger fluxes in winter and weaker currents in summer. The current through the Channel was mainly directed toward the northern basin such that the Corsica Channel can be considered as a one-way gate from the Tyrrhenian Sea towards the Ligurian-Provençal basin (Fig. 3).

Progressive diagrams (Fig. 4) show that transport during winter (up to $200 \mathrm{~km} / \mathrm{month}$ in November) was mainly northward. There were small westward components suggesting water coming from the Tuscan side of the Channel and going towards North Corsica where the WCC flows toward the Ligurian coast. 

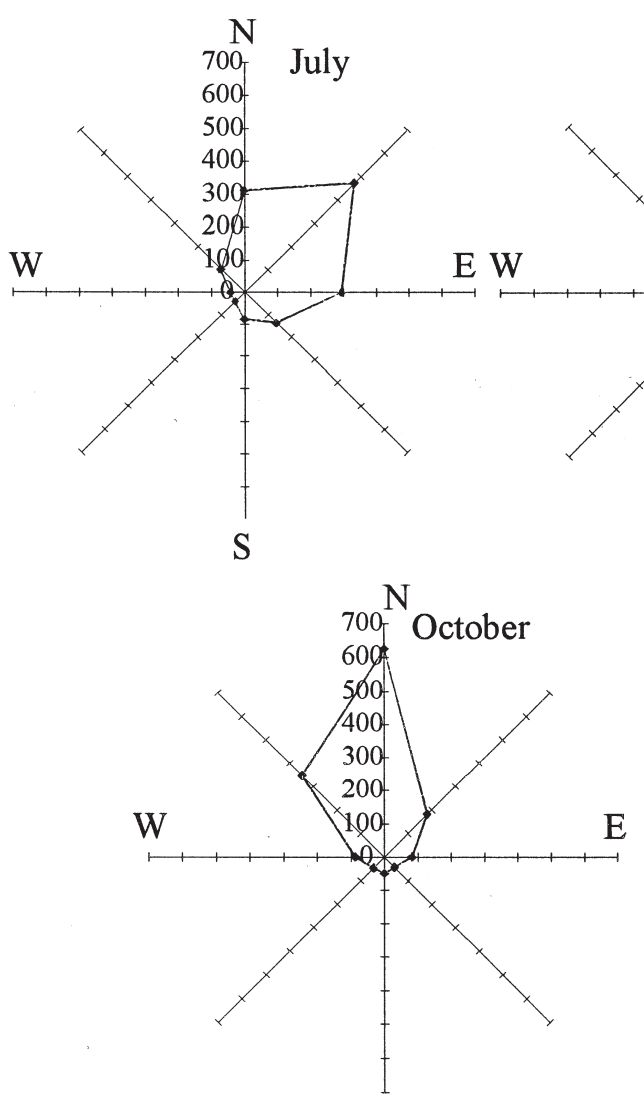

S
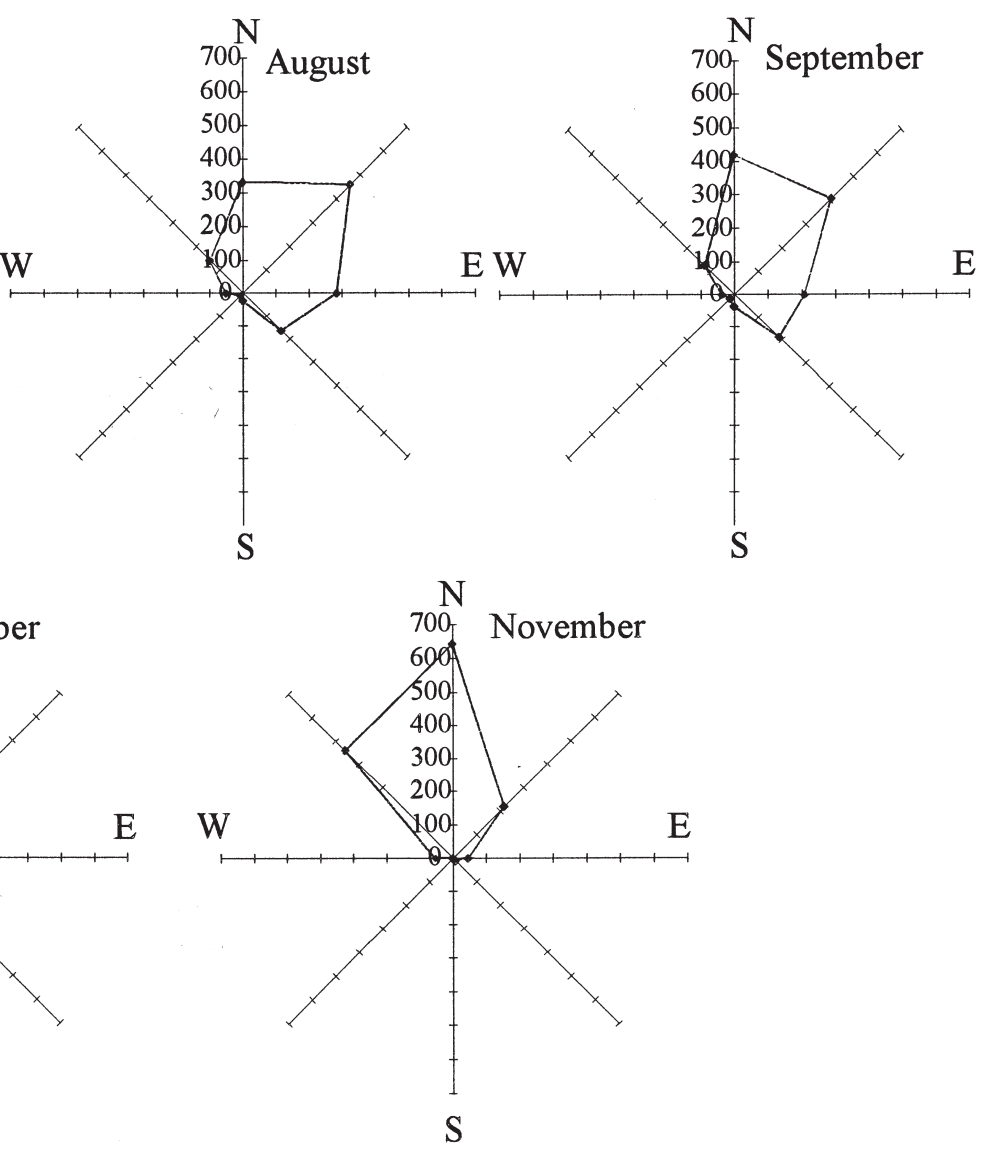

FIG. 3. - Monthly number of records for main directions. Currents are mainly directed toward the northern basin.

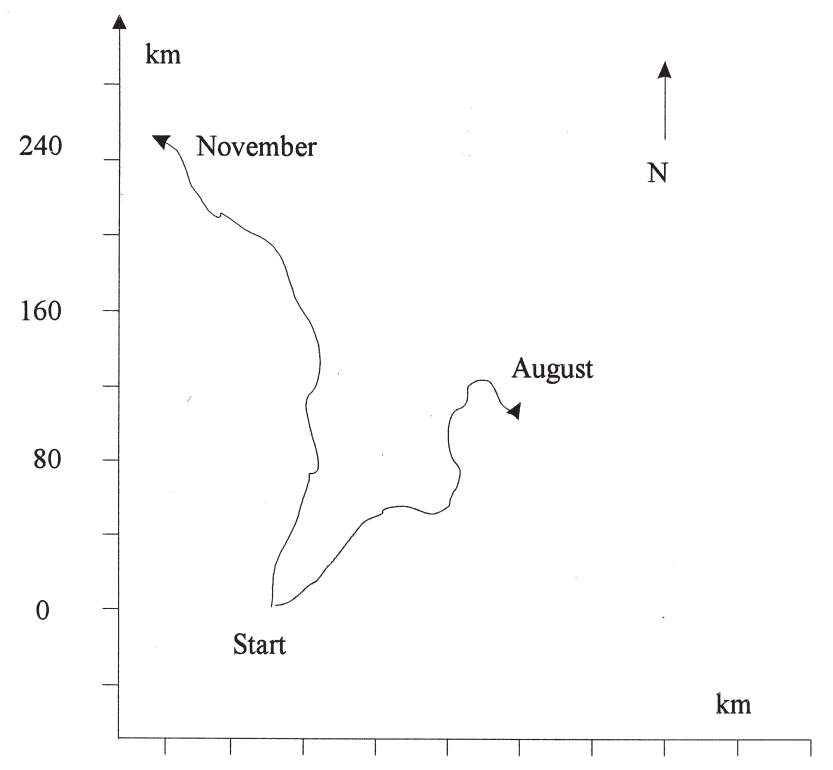

$-50$

110

190

FIG. 4. - Progressive diagrams of currents. Fluxes are stronger in winter than in summer.
During summer currents were weaker (100 $\mathrm{km} / \mathrm{month}$ in August) with temporary local recirculation. The northern transport had a more eastward component with water coming from the Corsica side and directed more toward the Tuscan Continental Shelf than to the Ligurian circulation. The monthly averaged components of currents in North-South and East-West directions are reported in fig. 5.

The average intensities of the component of current transverse to the section of the Channel were about 6-7 $\mathrm{cm} \mathrm{s}^{-1}$ toward the East in summer and $3 \mathrm{~cm}$ $\mathrm{s}^{-1}$ toward the West in winter.

Since the distances from the mooring to the coasts were about 10 and $20 \mathrm{~km}$, we can calculate that it would take the propagules approximately 80 hours from the Corsica coast to the mooring in summer and about 90 days from the Capraia coast to the mooring in winter.

\section{Benthos}

Macrobenthic species settled on all the items in the moorings but greater abundance was found at the 


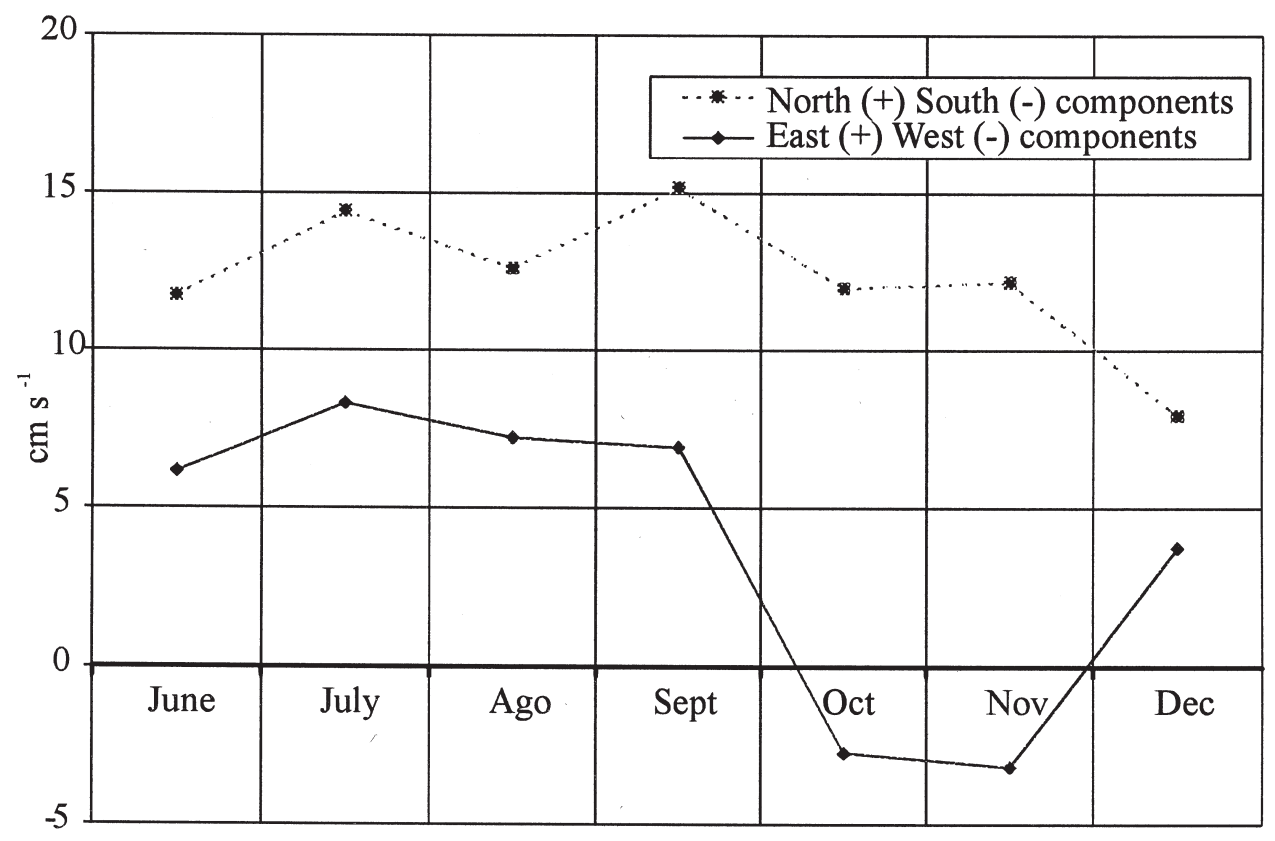

Months of 1993

FIG. 5. - Components of currents (monthly averages) along and across the Channel. Small westward components were recorded in the cold season.

shallower stations. The dominant species were the serpulid Spirobranchus polytrema and the mollusc Anomia ephippium found at stations A and B. Also common were the polychaete Nereis irrorata and the mollusc Modiolarca subpicta, whose specimens were included in small mucous and filamentous structures. A patchy mat of different species of hydroids covered almost all the instruments. Table 1 gives a semi-quantitative estimate of the abundance of species and some features of their dispersal strategies reported in literature.

Serpulids such as Spirobranchus polytrema release trochophores with weak swimming capability (maximum $5 \mathrm{~mm} / \mathrm{s}$ ). In the water column they become metatrochophores and feed in the plankton where they can survive up to eight weeks transported by currents. However, their length of life depends also on temperature, salinity and the amount of food (Bianchi, 1981). Serpulids can also settle on objects such as plants or plastics floating in the water; these rafting objects are an adequate substratum for colonisation of larvae and are a very important means of dispersal because they can be advected by currents for long periods.

The larvae of polychaetes of the family Nereididae have a very short pelagic life and are not often found in the plankton (Bhaud and Cazaux, 1988), but most species reproduce by the heteronereis stage that separates from the body of the worm and is transported away. The heteronereis stage is reported for both the species we found (Fauvel, 1923).

Dispersal of molluscs is widely studied and mainly focused on larvae (Thorson, 1950; Massé and Guérin, 1978; Johannesson, 1988; Scheltema, 1988; Martel and Chia, 1991; Bhaud, 1993) but other strategies have been found (Sigurdsson, 1976; Lane et al., 1985; Martel and Chia, 1991). The bivalves Modiolarca subpicta and species of the family Anomiacea have typical byssus modifications that allow floating of post-larval specimens (Sigurdsson, 1976). The method of transport is analogous to the gossamer flight of young spiders. Sigurdsson called this dispersal method "byssus drifting". All the specimens of Modiolarca subpicta we found were included in small mucous structures with trapped gas bubbles. It was not possible to identify whether this mucous was the byssus modification of young specimens suggested by Sigurdsson or a later mucous secretion, but this species had an unexpected potential floatation despite the heavy shell. Postmetamorphic drifting is a common strategy of dispersal (Martel and Chia, 1991) and even if it was not possible to identify the origin of these floating mucous structures, a dispersal strategy based upon an unexpected floatation was evidently present in the Corsica Channel. 
TABLE 1. - Dispersal strategies of species collected on current meter moorings in the Corsica Channel

\section{Abundance Stations Type of Sexual Byssus Medusae Rafting Free References}

larvae propagules drifting objects adults

\section{Cnidaria}

Clytia hemisphaerica (L.)

Lafoeina tenuis M.Sars

Laodicea undulata (Forbes and Goodsir)

Phialella quadrata (Forbes)

\section{Polychaeta}

Ceratonereis costae (Grube)

Harmothoe sp.

Hydroides elegans (Haswell)

Hydroides pseudouncinata Zibrowius

Hydroides sp.

Lysidice ninetta Audouin and Milne-Edwards

Melinna palmata Grube

Nereis cfr irrorata (Malmgren)

Nereis falsa Quatrefages

Platynereis dumerilii Audouin and Milne-Edwards

Serpula vermicularis L.

Spirobranchus polytrema (Philippi)

Syllis gracilis Grube

Syllis prolifera (Krohn)

\section{Mollusca}

Aequipecten opercularis (L.)

Anomia ephippium L.

Arca tetragona Poli

Atrina pectinata (L.)

Cavolinia inflexa (Lesueur)

Chlamys flexuosa (Poli)

Chlamys varia (L.)

Doto coronata (Gmelin)

Gastropoda indet.

Modiolarca subpicta (Cantraine)

Opistobranchia indet.

Palliolum incomparabile (Risso)

Pseudamussium clavatum (Poli)

Pteria hirundo (L.)

\section{Echinodermata}

Arbaciella elegans Mortensen

Arbacia lixula (L.)

Leptometra phalangium (J. Muller)

Psammechinus microtuberculatus (Blainville)

\section{A1 12 A 3 B D \\ A1 3 B D \\ A1 3 \\ A1 3 B 4 C 5}

$\begin{array}{cccl}\text { yes } & \text { yes } & \text { yes } & \text { Madin et al. } 1996 \\ \text { yes } & * & * & \text { Cornelius, 1992 } \\ \text { yes } & * & * & \text { Cornelius, 1992 } \\ \text { yes } & * & * & \text { Cornelius, 1992 }\end{array}$

Bhaud and Chazaux, 1988 Mileikovski, 1971

Bianchi, 1981 *

Bianchi, 1981 *

Bianchi, 1981 *

yes Bhaud and Chazaux, 1988

Bhaud and Chazaux, 1988 Bhaud and Chazaux, 1988 Bhaud and Chazaux, 1988

Bianchi, $1981 *$

Bianchi, 1981

Hayward and Ryland, 1990

Hayward and Ryland, 1990

Beumont and Barnes, 1992

Sigurdsson, 1976

Beumont and Barnes, 1992 Beumont and Barnes, 1992 Thompson, 1988

Martel and Chia, 1991
Tortonese, 1965

Tortonese, 1965

Tortonese, 1965

Tortonese, 1965

Pycnogonidae

Pycnogonida indet.

R A

Bryozoa

Aetea sp.

A3 12 A 3 B

* information inferred from closely related species or higher taxa;

$\mathrm{D}=$ dominant;

A1 =high abundance (more than 5 individuals);

A2 $=$ medium abundance (between 2 and 4 individuals);

A3 =low abundance (less than 2 individuals in more than 2 samples);

$\mathrm{R}=$ rare (less than 2 individuals); $\mathrm{P}=$ planktonic;

$\#$ = shallow or coastal species

In most Cnidarians the planula could be considered a larval dispersal phase but according to Boero and Bouillon (1987) it does not achieve the complexity implicit in this term and is only partly suitable for long range dispersal. Longer distances can be reached by medusa stages that are more complex phases of the life cycle and can be self-maintaining.
Other dispersal strategies were reported for hydroids that can live on rafting objects (Cornelius, 1992) or as free living fragments floating in the water column (Madin et al., 1996).

The most common fouling species of cirripeds and ascidians were totally absent from these samples. 


\section{CONCLUSIONS}

In the Corsica Channel the variability in current direction was low and flows were mainly directed toward the northern basin making this channel a one-way passage through the Tyrrhenian Sea and the Ligurian Sea. Only some small differences between summer and winter were found in the East-West components of current. These fluctuations are probably too small to affect the general fluxes of the mesoscale circulation but they may have some important biological implications if connected to length of life of dispersal strategies.

Apart from a few species, such as the very abundant Spirobranchus polytrema that has a planktonic life longer than 80 hours, most of the species found on the moorings have short planktonic lives and probably cannot survive in the water column for the 80-90 hours required to cover the distance to the mooring. Nevertheless, most of them are common to both basins.

Dispersal strategies based upon post-development processes, e.g. adults on rafting objects or free living fragments (Madin et al., 1996), are crucial to explain species distribution. Short larval phases are not a limiting factor for wide distribution. Species that commonly use also these strategies can be included in the widely spread "club of superwanderers" (Cornelius, 1992; Aliani et al, 1998). The pitfall of the assumption that dispersal potential based only from larval type or laboratory observations of the duration of the pelagic larval stage should be considered (Todd, 1998).

Only very few species with prolonged planktonic larvae were found. Remarkable amongst them is the Echinoid Arbaciella elegans. This species was found in the Southern basins of the Mediterranean Sea some time ago but some indications of northward migration were found along the Sicilian coasts (Giacobbe and Rinelli, 1992) and Sardinia coasts (Solinas, 1989). After discovery in the Corsica Channel the species was then found for the first time on the Ligurian Coast close to Loano (Signorelli and Zamboni, 1998) confirming that its distribution had extended northward.

Warm water species entering the Ligurian Sea as suggested by Astraldi et al. (1993), and Arbaciella is only one example, pass through the "gate" of the Corsica Channel. The "gate" can be open or closed for migrations according to the variability of currents but also according to the dispersal strategies of species. Northward flux variability may have bio- geographical relevance in maintaining the separation between the two basins because most fast transport takes place in winter when most of the "warm" species are in unfavourably cold conditions. Only a few species can pass the gate and find suitable habitat in northern warm oases where they settle (Bianchi and Morri, 1992).

Change in communities depends on direct effects of climatic parameters, e.g. temperature, which alter individual survival and interactions between species at a local scale but also indirectly at mesoscale by variability in water flow and current patterns (Southward, 1995). Temperature is the control factor for a reproducing population (Bouchet and Taviani, 1992; Bianchi, 1998) but the role of current variability at the boundary of the Ligurian Basin in controlling migration had been underestimated although borders are best witnesses of migrations between two biogeographical units (Angel, 1991).

As stressed by Barry and Dayton (1991), it is the existence of physical factors acting together with biotic relationships that controls the distribution of organisms. Nonetheless, although it is widely accepted that the contribution of dispersal forms from the water column is a source of potential variability (Lewin, 1986; Roughgarden et al., 1988, Boero, 1994), with biogeographic and climatological implications, studies concerning the coupling of physical and biological processes are still rare.

\section{ACKNOWLEDGEMENTS}

We wish to thank the Captain and the crew of the Oceanographic Ship Urania; A.M. De Biasi (Livorno), C.N. Bianchi (La Spezia), C. Morri (Genova) for suggestions on the biological part of the study and identification of some species; M. Astraldi and G.P. Gasparini (La Spezia) for suggestions on the physical oceanography part; and C. Galli, E. Lazzoni, F. Degl'Innocenti and M. Borghini (La Spezia) for help working at sea. Physical data were collected within projects funded by EC MAST-MTP and by the Physical Committee of CNR, and the biological data within the project SINAPSI.

\section{REFERENCES}

Abbiati, M., C.N. Bianchi, A. Castelli, A. Giangrande and C. Lardicci. - 1991. Distribution of polychaetes on hard substrates of the midlittoral-infralittoral transition zone, Western Mediterranean. Ophelia, 5: 421-432. 
Albertelli, G., M. Cattaneo and N. Drago. - 1981. Macrobenthos du plateau continental ligure et de l'Archipel toscan: aperçus zoogeographiques. Rapp. Comm. int. Mer Médit., 27(2): 127-128.

Aliani, S. - 1994. I fondi a Gryphus vitreus (Brachiopoda) dell'Arcipelago toscano (Mediterraneo Occidentale). Atti X Congr. A.I.O.L.: 209-220

Aliani, S., C.N. Bianchi and C. Morri. - 1995. Lineamenti del benthos dei mari toscani. Atti Soc. Tosc. Scienze Nat., 7 (suppl.), mem. serie A: 77-92.

Aliani, S. and R. Meloni. - 1996. Relationship between transport of benthic species and hydrological characteristics: note on settlement in the Corsica Channel. Atti XI Congr. A.I.O.L.: 259-269.

Aliani, S., C. De Asmundis, R. Meloni, M. Borghini and G.P. Gasparini. - 1998. Transport of benthic species in the Sicily Channel: preliminary observations. Atti XII Congr. A.I.O.L. 2: 173182 .

Angel, M.V. - 1991. Variation in time and space: is biogeography relevant to studies of long-time scale change? J. mar. biol. Ass. $U K, 71: 191-206$

Artale, V., M. Astraldi, G. Buffoni and G.P. Gasparini. - 1994. Seasonal variability of gyre-scale circulation in the northern Tyrrhenian sea. J. Geoph. Res., 99(C7): 14127-14137.

Artale, V. and G.P. Gasparini. - 1990. Simultaneous temperature and velocity measurements of the internal wave field in the Corsica Channel (Eastern Ligurian Sea). J. Geoph. Res., 95(2): 1635-1645.

Astraldi, M., C.N. Bianchi, G.P. Gasparini and C. Morri. - 1995. Climatic fluctuations, current variability, and marine species distribution: a case study in the Ligurian Sea (North-West Mediterranean). Oceanologica Acta, 18(2): 139-149.

Astraldi, M. and G.P. Gasparini. - 1992. The seasonal characteristics of the circulation in the North Mediterranean basin and their relationship with the atmospheric-climatic conditions. $J$. Geoph. Res. 97(6): 9531-9540.

Balduzzi, A., C.N. Bianchi, F Boero, B. Burlando, R. CattaneoVietti, R. Manconi, C. Morri, M. Pansini, R. Pronzato and U. Salghetti-Drioli. - 1986. Premières observations sur la distribution des biocénoses littorales de substrat dur de l'ile de Capraia (Archipel Toscan) par deux méthodes de relèvement en plongée. Rapp. Comm. int. Mer. Médit., 30(2): 263.

Barry, J.P. and P.K. Dayton. - 1991. Physical heterogeneity and the organization of marine communities. In: J.Kolasa and S.T.A. Picket (eds), Ecological heterogeneity. Springer-Verlag, 86: 270-320

Beumont, D.A. and D.A. Barnes. - 1992. Aspects of veliger larval growth and byssus drifting of the spat of Pecten maximus and Aequipecten (Chlamys) opercularis. J. Mar Sci. 49(4): 417:423.

Bhaud, M. - 1983. Les limites de distributions géographiques chez quelques invértébres marins. Oceanis, 9(4): 317-335.

Bhaud, M. - 1993. Relationship between larval type and geographic range in marine species: complementary observations on gastropods. Oceanologica Acta, 16(2): 191-198.

Bhaud M. -1998 . The spreading potential of polychaete larvae does not predict adult distributions; consequences for conditions of recruitment. Hydrobiologia, 375-376: 35-47.

Bhaud, M. and C. Cazaux. - 1988. Description and identification of polychaete larva; their implication in current biological problems. Oceanis, 13(6): 596-753.

Bianchi, C.N. - 1981. Policheti serpuloidei. In: Guide per il riconoscimento delle specie animali delle acque lagunari $e$ costiere italiane. CNR Roma, AQ/1/96 5, $187 \mathrm{pp}$.

Bianchi, C.N., I. Ceppodomo, C. Galli, S. Sgorbini, F. Dell'Amico and C. Morri. - 1993. Benthos dei mari toscani. I: Livorno-Isola d'Elba (Crociera Enea 1985). In: O. Ferretti, F. Immordino, V. Damiani (eds.), Arcipelago toscano, studio oceanografico, sedimentologico geochimico e biologico, pp. 263-290. Enea, Roma.

Bianchi, C.N. and C. Morri. - 1994. Southern species in the Ligurian Sea (Northern Mediterranean): new records and a review. Boll. Ist. Mus. biol. Univ. Genova, 58/59(1992-1993): 181-197.

Bianchi, C.N. - 1988. Climate change and biological response in the marine benthos. Atti XII Congr. A.I.O.L. 2: 3-20.

Boero, F. - 1994. Fluctuations and variations in coastal marine environments. Mar. Ecol. P.S.Z.N.I., 15(1): 3-25.

Boero, F. and J. Bouillon. - 1993. Zoogeography and life cycle pattern of Mediterranean hydromedusae (Cnidaria). Biol. Jour. Linn. Soc., 48: 239-266.

Bouchet, P. and M. Taviani. - 1992. The Mediterranean deep-sea fauna: pseudopopulations of Atlantic species? Deep-Sea Res., 39(2): 169-184

Cornelius, P.F.S. - 1992. Medusa loss in leptolid Hydrozoa (Cnidaria), hydroid rafting, and abbreviated life-cycles among their remote-island faunae: an interim review. Sci. Mar., 56 (23): 245-261.

De Vantier, L.M. - 1992. Rafting of tropical marine organisms on buoyant coralla. Mar Ecol. Prog. Ser. 86: 301-302.

Emig, C.C. - 1985. Distribution et synécologie des fonds à Gryphus vitreus (Brachiopoda) en Corse. Mar. Biol., 90: 139-146.

Fauvel, P. - 1923. Faune de France. Fascicule 5: Polychaetes errantes. Paris, Edition du Muséum: 1-488.

Giacobbe, S. and P. Rinelli,- 1992. Ecological notes on Arbaciella elengans (Mortensen) from populations of Pinna in the strait of Messina. In: Echinoderm Research. Scalera. Riaci L., Canicatti C (eds). Proc. $3^{\text {rd }}$ Europ. Conf. on Echinoderms. Publ. by AA.VV Balkema, Rotterdam, Nederlands: 185-190.

Giangrande, A., S. Geraci and G. Belmonte. - 1994. Life cycle and life-history diversity in marine invertebrates and the implications in community dynamics. Ocean. Mar. Biol. Ann. Rev., 32: 305-333.

Hayward, P.J. and Ryland, J.S. - 1990. The marine fauna of the British Isles and north West Wales. Vol I. Clarendon Press, Oxford: 1-627.

Harmelin, J.G. and J.L. d'Hondt. - 1992. Transfers of bryozoans between the Atlantic Ocean and the Mediterranean Sea via the Strait of Gibraltar. Oceanologica Acta, 16(1): 63-72.

Hopkins, T.S. - 1988. Recent observations on the intermediate and deep water circulation in the Southern Tyrrhenian sea. In: Océanographie pélagique méditerranéenne. H.J. Minas and P. Nival (eds.), pp. 41-50. Oceanologica Acta n. sp.

Jamada, S.B. - 1989. Are direct developers more locally adapted than planktonic developers? Mar. Biol., 103: 403-411.

Johannesson, K. - 1988. The paradox of Rockall, why is a brooding gastropod (Littorina saxatilis) more widespread than one having a planktonic larval dispersal stage (L. littorea)? Mar. Biol., 99: 507-513

Lane, D.J.W., A.R. Beaumont and J.R. Hunter. - 1985. Byssus drifting and the drifting threads of the young post-larval mussel Mytilus edulis. Mar. Biol., 84: 301-308.

Lewin, R. - 1986. Supply side ecology. Science, 234: 25-27.

Madin, L.P., S.M. Bollens, E. Horgan, M. Butler, J. Runge, B.K. Sullivan, G. Klein-Macphee, E. Durbin, A.G. Durbin, D. Van Keuren, S. Plourde, A. Bucklin and E. Clarke. - 1996. Voracious planktonic hydroids: unexpected predatory impact on a coastal marine ecosystem. Deep-Sea Res., 43(7-8): 1823-1829.

Martel, A. and F.S. Chia. - 1991. Drifting and dispersal of small bivalves and gastropods with direct development. J. Exp. Mar. Bio. Ecol., 150: 131-147.

Massé, H. and J.P. Guérin. - 1978. Etude expérimentale sur le recruitment des espèces de la macrofaune benthique des substrats meubles. 2. Données sur le cycles biologiques des polychetes et des bivalves. Tethys, 8(3): 283-294.

Mileikovsky, S.A. - 1968. Some common features in the drift of pelagic larvae and juvenile stages of bottom invertebrates with marine currents in temperate regions. Sarsia, 34: 209-216.

Mileikovsky, S.A. - 1971. Types of larval development in marine bottom invertebrates, their distribution and ecological significance, a re-evaluation. Mar. Biol., 10: 193-213.

Pedrotti, M.L. and L. Fenaux. - 1996. Distribution of echinoderm larval populations in the geostrophic frontal jet of the eastern Alboran Sea. Oceanologica Acta, 19(3-4): 385-393.

Roughgarden, J., S. Gaines and H. Possingham. - 1987. Recruitment dynamics in complex life cycles. Science, 241: 14601466.

Scheltema, R.S. - 1971. Larval dispersal as a mean of genetic exchange between geographically separated populations of shallow-water benthic marine gastropods. Biol. Bull., 140(2): 284-322.

Scheltema, R.S. - 1988. Initial evidence for the transport of teleplanic larvae of benthic invertebrates across the east Pacific barrier. Biol. Bull., 174: 145-152.

Signorelli, M. and A. Zamboni. - 1998. Segnalazione di Arbaciella elegans Mortensen, 1910 (Echinoidea, Arbaciidae) in Mar Ligure. Biol mar. Medit. 5(1) part2: 644-645.

Sigurdsson, J.B. - 1976. The dispersal of young post-larval bivalve molluscs by byssus threads. Nature, 262: 386-387. 
Solinas, P.L. - 1989. Presence of Arbaciella elegans Mortensen, 1910 (Echinoidea Arbaciidae) in the Italian waters. Mar Life. 10: 73-75.

Southward, A.J. - 1995. The importance of long time-series in understanding the variability of natural systems. Helgolander Meerestunters., 49: 329-333.

Thiriot-Quievreux, C. - 1969. Caractéristiques morphologiques des véligers planctoniques de gastropodes de la région de Banyulssur-mer. Vie Milieu, 2 (B): 333-366.

Thompson, T.E. -1988 . Molluscs: benthic opistobranchs. In: Syn- opses of the British Fauna (new series). Kermach and Barnes (eds). 8: 1-356.

Thorson, G. - 1950. Reproduction and larval ecology of marine bottom invertebrates. Biol Rev., 25: 1-45.

Todd, C.D. - 1998. Larval supply and recruitment of benthic invertebrates: do larvae always disperse as much as we believe? Hydrobiologia, 375/375: 1-21.

Tortonese, E. - 1965. Echinodermata. Calderini, Bologna 1-422.

Scient. ed.: J.M. Gili 